\section{Weed Control in Pejibaye Heart of Palm Plantations in Hawaii}

\author{
Joseph DeFrank ${ }^{1}$ and Charles R. Clement ${ }^{2}$ \\ Department of Horticulture, University of Hawaii at Manoa, 3190 Maile Way, \\ Honolulu, HI 96822-2279
}

Additional index words. Bactris gasipaes, peach palm, precocity, yield, polypropylene mat, herbicide, oxyfluorfen, oryzalin, paraquat

\begin{abstract}
Pejibaye (Bactris gasipaes Kunth, Palmae) is being evaluated for production of fresh heart of palm in Hawaii. Precocity, yields, and weed control were evaluated in response to woven black polypropylene mat (control), oryzalin, oxyfluorfen, and paraquat. Control plots attained $100 \%$ of plants harvested by 26 months, followed by oxyfluorfen $(97.5 \%)$, oryzalin $(77.5 \%)$, and paraquat $(60 \%)$. Estimated heart of palm yields $(3731$ plants/ha) were similar with oxyfluorfen $1.2 \mathrm{~kg}$ a.i./ha $\left(707 \mathrm{~kg}^{-} \cdot \mathrm{a}^{-1}\right)$, polypropylene mat $\left(612 \mathrm{~kg} \cdot \mathrm{ha}^{-1}\right)$, oxyfluorfen $0.6 \mathrm{~kg}$ a.i./ha $\left(600 \mathrm{~kg} \cdot \mathrm{ha}^{-1}\right)$, and oryzalin $4.5 \mathrm{~kg}$ a.i./ha $(478$ $\left.\mathrm{kg} \cdot \mathrm{ha}^{-1}\right)$. Based on precocity, yields, and weed control efficiency, the performance rating of these weed control treatments was mat $\approx$ oxyfluorfen $>$ oryzalin $>$ paraquat. Chemical names used: 4-(dipropylamino)-3,5-dinitrobenzenesulfonamide (oryzalin); 2-chloro-1-(3ethoxy-4-nitrophenoxy)-4-(trifluoromethyl)benzene (oxyfluorfen); 1,1'-dimethyl-4-4'bibyridinium ion (paraquat).
\end{abstract}

Pejibaye is being evaluated as a potential new crop for production of fresh heart of palm in Hawaii (Clement et al., 1993). The heart of palm is a gourmet vegetable composed of the tender leaves just above the palm's apical meristem. The fresh market also accepts the tender stem just below the palm's apical meristem and the tender leaves just above the heart of palm. Weed control in commercial plantations in Costa Rica and other Latin American countries is labor-intensive, partially because of an early report on herbicide damage to pejibaye, especially by paraquat (Saénz Chaverri, 1978). The objective of the current study was to evaluate palm yields and weed control in response to woven black polypropylene mat and sequential applications of oryzalin, oxyfluorfen, and paraquat.

\section{Material and Methods}

The experiment was conducted at Waimanalo Agricultural Experiment Station, Waimanalo, Oahu, Hawaii (lat. $21^{\circ} 20^{\prime} 15^{\prime \prime} \mathrm{N}$; long. 157 $\left.43^{\circ} 30^{\prime \prime} \mathrm{W}\right)$. The soil is a Mollisol, Cumulic Haplustoll, Kawaihapai Series, gravelly clay loam. The climate is classified as Aw

Received for publication 27 Mar. 1995. Accepted for publication 17 June 1995. Hawaii Institute of Tropical Agriculture and Human Resources Journal series no. 4078. Financed by the Committee for Agricultural Product Expansion of the Governor's Agriculture Coordinating Committee, Hawaii. Use of trade names does not imply endorsement of the products named nor criticism of similar ones not named. The cost of publishing this paper was defrayed in part by the payment of page charges. Under postal regulations, this paper therefore must be hereby marked advertisement solely to indicate this fact.

${ }^{1}$ Professor.

${ }^{2}$ Research Assistant

${ }^{3}$ Instituto Nacional de Pesquisas da Amazonia, Cx. Postal 478, 69011-920 Manaus, AM, Brasil in the Köppen system. The design was a randomized complete block, with four openpollinated progenies from the Benjamin Constant (Brazil) population of the Putumayo landrace used as replications. Plot size was 2.8 $\times 4.9 \mathrm{~m}$, with five plants in a staggered pattern (3731 plants/ha). The period reported here is from planting (21 July 1992) to 26 months in the field, which includes establishment and the first harvest cycle.

Site preparation involved installation of overhead irrigation to flush weeds, which were killed with two sequential applications of $\mathrm{N}$ (phosphonomethyl)glycine (glyphosate) (Roundup; Monsanto, St. Louis) at $1.0 \mathrm{~kg}$ a.i./ ha. Planting holes $(30 \mathrm{~cm}$ in diameter, 45 to 50 $\mathrm{cm}$ deep) were made with a tractor-mounted auger. Six-month-old seedlings were planted and received $100 \mathrm{~g}$ treble superphosphate $(0 \mathrm{~N}-$ $19.8 \mathrm{P}-0 \mathrm{~K}), 80 \mathrm{~g}$ Osmocote $17 \mathrm{~N}-2.6 \mathrm{P}-8.3 \mathrm{~K}$, two $19-\mathrm{g}(28 \mathrm{~N}-3.4 \mathrm{P}-3.3 \mathrm{~K})$ and two $10 \mathrm{-g}$ (20N-4.3P-4.2K, with minors) slow-release tablets in the planting pit, and $100 \mathrm{~g} \mathrm{21N}-3 \mathrm{P}-$ $11.6 \mathrm{~K}$ fast-release fertilizer after 6 months and every 3 months thereafter. Overhead sprinkler irrigation provided $\approx 20$ liters/plant twice a week.

The preemergence herbicide treatments consisted of oryzalin (Surflan; DowElanco, Indianapolis) at 4.5 and $9.0 \mathrm{~kg}$ a.i./ha and oxyfluorfen (Goal; Rohm and Haas, Philadelphia) at 0.6 and $1.2 \mathrm{~kg}$ a.i./ha and were applied 79, 177, 288, and 386 days after planting (DAP). Paraquat (Gramoxone Extra; Zeneca, Wilmington, Del.) at 1.2 and $2.4 \mathrm{~kg}$ a.i./ha was the only postemergence herbicide. It was applied as a finished spray, with a nonionic surfactant at $0.1 \%(\mathrm{v} / \mathrm{v})$, on $79,177,328$, and 440 DAP. All herbicides were applied with a $\mathrm{CO}_{2}$-powered backpack sprayer with an open boom at an operating pressure of $118 \mathrm{kPa}$ and a carrier volume of 350 liters $\cdot h^{-1}$. This method allowed spray to contact the base of the palms and associated suckers. Woven black poly- propylene mat (PAK Groundcover Weed Screen; Pak Unlimited, Norcross, Ga.) served as the control.

Weeds were removed manually before reapplication of the preemergence herbicides. The time required for a five-person crew to return plots to a weed-free condition was recorded. A representative hand weeding was recorded on 30 Nov. 1993 and occurred 103 days after the previous preemergence spray application and 57 days after application of paraquat. Analysis of durations was done on natural logarithmically transformed data.

Plants that were at least $1.3 \mathrm{~m}$ tall (measured at the fork of the first fully expanded leaf and the flag leaf) were harvested at 500, 656, and 779DAP. After stripping away the fibrous petiole sheaths, three edible portions were obtained: the edible stem, composed of the actively differentiating and expanding stem just below the apical meristem; the heart of palm, composed of the expanding leaves above the meristem wrapped within the petiole-sheath of the flag leaf; and the edible leaf, composed of the expanding leaves above the heart that are not wrapped within the petiole-sheath of the flag leaf. Each portion has distinct texture and culinary characteristics, but only the heart of palm is currently available on the market as a canned product. Two yields are reported: 1) heart, for direct comparison with Latin American results; and 2) total edible product, to better reflect yield for the fresh market. Both yields were estimated by a direct scaling from plot yields to a per hectare basis, and must be used with caution. Precocity of yield is defined as the number of days after planting when $60 \%$ of the plants in each plot were harvestable (60\% was chosen because of reduced growth in the paraquat treatments at the end of the observations).

\section{Results and Discussion}

Harvest started at 500 DAP, 421 days after treatment initiation. At this time, the polypropylene mat had the highest percentage of plants harvested $(80 \%)$, followed by oxyfluorfen $(50 \%)$, paraquat $(20 \%)$, and oryzalin $(12.5 \%)$. Estimated palm heart yields, adjusted for percent harvest, were higher with the polypropylene mat and both rates of oxyfluorfen than with most of the other treatments (Table 1). Oryzalin and the higher rate of paraquat caused the most substantial yield reductions. In all subsequent harvests, the high rate of oryzalin and both rates of paraquat reduced yields in comparison with the polypropylene mat. By the end of the experiment (779 days), the best heart yields were slightly lower than similarly aged Costa Rican yields (Mora Urpí, 1992), when transformed to a 5000-plant/ha equivalence (the commercial density). Total edible yield showed a similar response to the weed control treatments (Table 1).

Oxyfluorfen did not significantly reduce growth of pejibaye, but both oryzalin and paraquat caused growth reduction (data not shown). Oryzalin-treated plants showed signs of improved vigor at the last harvest (393 days after the last herbicide application). The re- 
Table 1. Precocity, accumulated estimates of palm heart, and total edible product yields at three harvests, and a representative time to control residual weeds, during the first harvest cycle of a pejibaye heart of palm plantation in Hawaii.

\begin{tabular}{|c|c|c|c|c|c|c|c|c|c|}
\hline \multirow[b]{2}{*}{ Treatment } & \multirow{2}{*}{$\begin{array}{c}\text { Rate } \\
\left(\mathrm{kg} \cdot \mathrm{ha}^{-1}\right)\end{array}$} & \multirow{2}{*}{$\begin{array}{l}\text { Precocity } \\
\text { (days) }\end{array}$} & \multicolumn{3}{|c|}{$\begin{array}{c}\text { Yield of heart } \\
\left(\mathrm{kg} \cdot \mathrm{ha}^{-1}\right)\end{array}$} & \multicolumn{3}{|c|}{$\begin{array}{c}\text { Total edible yield } \\
\left(\mathrm{kg} \cdot \mathrm{ha}^{-1}\right)\end{array}$} & \multirow{2}{*}{$\begin{array}{c}\text { Time to } \\
\text { weed free }^{\mathrm{x}}\end{array}$} \\
\hline & & & 500 & 656 & 779 & 500 & 656 & 779 & \\
\hline Polypropylene & & 390 & 469 & 576 & 612 & 1685 & 2079 & 2201 & 0 \\
\hline \multirow[t]{2}{*}{ Oxyfluorfen } & 0.6 & 535 & 318 & 558 & 600 & 1161 & 1953 & 2116 & 15 \\
\hline & 1.2 & 540 & 409 & 672 & 707 & 1467 & 2357 & 2469 & 14 \\
\hline \multirow[t]{2}{*}{ Oryzalin } & 4.5 & 675 & 89 & 365 & 478 & 320 & 1246 & 1631 & 56 \\
\hline & 9.0 & 690 & 74 & 242 & 382 & 279 & 910 & 1404 & 54 \\
\hline \multirow[t]{2}{*}{ Paraquat } & 1.2 & 682 & 187 & 278 & 334 & 916 & 1314 & 1531 & 52 \\
\hline & 2.4 & 830 & 92 & 225 & 313 & 330 & 682 & 1041 & 56 \\
\hline $\operatorname{LSD}_{(0.05)}$ & & 163 & 200 & 189 & 169 & 868 & 719 & 645 & 2 \\
\hline
\end{tabular}

${ }^{\mathrm{z}}$ The harvests $(500,656,779)$ are counted in days after planting.

y In days after planting to harvest $60 \%$ of the plants in the plots.

${ }^{x}$ Time (seconds) required to manually return the plot to a weed-free condition with five people.

duced growth with oryzalin was attributed to inhibition of root growth (Parka and Soper, 1977). Pejibaye, like palms in general, has a very superficial, fibrous root system. Paraquattreated leaves were severely damaged, especially on the suckers. The shady conditions within the canopy may have enhanced paraquat absorption by the leaf blade and the petiole sheath of both the main stem and the suckers, with subsequent translocation and systemic damage (Ashton and Monaco, 1991). The observed growth and yield reductions confirm Saénz Chaverri's (1978) report of paraquat injury to pejibaye in Costa Rica.

The predominant weeds present were Eleusine indica (L.) Gaertn., Chamaesyce hirta (L.) Millsp. (= Euphorbia hirta L.), and Sigesbackia orientalis L.
Based on precocity, yields, and weed control efficiency, the performance rating of these weed control treatments was mat $\approx$ oxyfluorfen $>$ oryzalin > paraquat. Polypropylene mat is already being used in the first commercial plantations in Hawaii, and a nonbearing label has been requested for oxyfluorfen.

\section{Literature Cited}

Ashton, F.M. and T.J. Monaco. 1991. Weed science-Principles and practices. Wiley, New York.

Clement, C.R., R.M. Manshardt, J. DeFrank, F.Zee, and P. Ito. 1993. Introduction and evaluation of pejibaye (Bactris gasipaes) for palm heart production in Hawaii, p. 465-472. In: J. Janick and J.E. Simon (eds.). New crops. Wiley, New York.

Mora Urpí, J. 1992. Bases para evaluar comercialmente futuras inovaciones en el cultivo de pejibaye para palmito. Boletin Pejibaye (Guilielma) 4(1):18-19. (Serie Técnica, Universidad de Costa Rica, San José.)

Parka, S.J. and Q.F. Soper. 1977. The physiology and mode of action of the dinitroaniline herbicides. Weed Sci. 25:79-87.

Saénz Chaverri, A. 1978. Control de malas hierbas en el cultivo del pejibaye. Asociación Bananera Nacional (Costa Rica) 3(7):10-11. 